THE committee is empowered to arrange meetings of the Division, to co-ordinate work dealing with the social relations of science, both at home and abroad, to be prepared to act in a consultative capacity and to supply information to organizations, individuals, and the public, to initiate and carry out inquiries and research, and to secure their publication. An executive sub-committee has prepared an extensive programme of work for the full committee, which, at a meeting on November 28, appointed a number of other sub-committees to deal with specific matters. These include such topics as the economic requirements of nations, the influence of scientific and technical developments on the relative importance of different industries and on the total volume of employment, the question of supplementing existing national research organizations whether in normal circumstances or at time of emergency, and the coordination and subsequent public presentation of work on nutrition and agriculture. Contact has already been established with organizations at work on such subjects as a survey of research in Great Britain, the prospective effects of changes in the population structure on economics, society, and occupations, and the incidence of taxation on scientific research. It is hoped to co-operate with the International Council of Scientific Unions, which has already set up a Committee on Science and its Social Relations with the view of preparing a report of world-wide scope.

\section{Jundhi Shapur}

AT a meeting of the Section of the History of Medicine of the Royal Society of Medicine on November 2, Dr. Cyril Elgood gave an interesting account of Jundhi Shapur, which was famous as the site of a university in south-west Persia, probably founded about A.D. 340. The Arab invasion of Persia took place when .Jundhi Shapur was at the height of its fame. The city surrendered in A.D. 636, but was left undisturbed, and the University remained the greatest centre of medical learning in the Islamic world until the foundation of the school of medicine in Bagdad. The system of medicine taught at Jundhi Shapur was predominantly Greek, but indigenous medicine, Indian medicine, and possibly Chinese medicine were also studied there. The teachers of Hippocratic medicine were reinforced by the exodus of the Nestorian professors from Edessa in 489 and of the Neo-Platonists from Athens in 529. There was also a constant flow of individual Greek physicians to the Persian royal service. The importance of Jundhi Shapur lay in its being a store-house of Greek tradition when Rome was no longer the capital of the Empire and when Constantinople was more interested in theology than in science. It was the cradle of the great Arabian school of medicine and provided most of the translators who rescued Greek texts from oblivion, thus forming the source of the renaissance of medicine in Europe. Owing, however, to the constant transfer of physicians to Bagdad, the school of Jundhi Shapur declined, and by the twelfth century ceased to function.

\section{Awards of the Mary Kingsley Medal}

Presentations of the Mary Kingsley Medal to five recipients were made on Novembor 23 at a reception at the Liverpool School of Tropical Medicine by its chairman, Viscount Leverhulme. This medal, struck in commemoration of the late Miss Mary Kingsley, niece of Charles Kingsley, distinguished for her work in promoting the welfare of the natives of West Africa, is awarded in recognition of services in the cause of fighting and preventing disease in the tropics. After the chairman had welcomed the guests, Prof. Warrington Yorke introduced the recipients of the medals, briefly outlining the grounds for the awards. They were : Lady Danson, honorary recipient, widow of the late Sir Francis Danson, who was Chairman of the Liverpool School over a lengthy period, and was largely responsible for the establishment of the School's research laboratory at Freetown, West Africa, and herself undertaking the duties of chairman during her husband's absences; Dr. Marshall A. Barber, with a long and distinguished association with the International Health Division of the Rockefeller Foundation, and recognized for his researches on malaria and for his work on the hookworm, and inventor of the 'micromanipulator' ; Prof. Emile Brumpt, of the University of Paris, distinguished for his researches on tropical parasitology ; Prof. W. Scott Patton, emeritus professor of entomology in the School, formerly in the Indian Medical Service and director of the King Institute, Madras, well known for his researches on kala-azar and oriental sore, and finally Werner Schuleman, professor of pharmacology, University of Bonn, the discoverer of the anti-malarial drug, plasmoquine, which gave a great impetus to chemotherapy.

\section{Early Anatolian Civilizations}

Miss Winifred Lamb's account of her third season of excavation at Kusuru, south-west of Afyon Karahissar in Anatolia, which was given before the Society of Antiquaries of London on November 17, emphasized the importance of this little-explored region for knowledge of the cultural distributions of Asia Minor in the third millennium B.C. Miss Lamb was able to demonstrate that at this early period the distinction which has been drawn between the cultures of eastern and western Anatolia is by no means so clearly defined as has been thought. The culture of the community of Kusuru in the third millennium, she finds, had much in common with that of the western Anatolian group; and she would regard the two, not indeed as dissociated, but rather as independent developments of the culture of peoples of a common stock. A relatively advanced stage of civic development is indicated by the disposition of the houses on either side of a street. These architectural remains are well preserved, and in some instances still rise to a height of more than three metres. A period of disturbances and the partial destruction of the settlement at about 2000 B.c. was followed by the appearance of a new race. The town was rebuilt and its citadel enclosed by a double wall with a gateway on the west. On the evidence of the pottery, implements and cult objects, 
it is possible to conclude that this new people was identical with that which formed the bulk of the population of the chief Hittite centres at Boghazkoi, Alishar and Alaga. This is the first occasion on which this culture has been found so far to the south-west. Its presence here may be expected to throw light on the difficult ethnological and historical problems of the second millennium B.C.

\section{Prehistoric Pottery in Kent}

THE results of further excavations in the Bean Valley, Kent, upon which Mr. J. P. T. Burchell made a report before the Society of Antiquaries of London on November 24, have failed to support the suggestion that the pottery discovered here in a previous investigation was of palæolithic age (see NATURE, 140,800 ; 1937.) The evidence upon which $\mathrm{Mr}$. Burchell relied in making such a suggestion was in part the absence of a mesolithic culture in the lower beds of the series in which the pottery occurred, in part the presence in the deposits of shells of the extinct Helicella striata, not previously recognized later than the Upper Palæolithic. Mr. Burchell's further examination of the site leads him to agree with the dissentient opinion previously expressed that this pottery is to be assigned to the early bronze age. It has been shown by this season's excavation that Helicella striata outlived the last glacial phase and survived into the mesolithic period. What was thought to be collateral evidence from Springhead in the Ebbsfleet valley in the form of striated implements showing the effect of glacial action has now proved to be later in date than two mesolithic floors in the valley, and consequently some other explanation of their condition must be sought. The excavations in the Ebbsfleet valley in the course of this further investigation have been pursued in exceptionally favourable conditions owing to pumping operations. It was found possible to excavate the bed of the stream to a depth of ten feet, and remains of cooking pots, decorated within and without, of a type not previously found in Britain, with flint flakes and fragments of worked wood of late mesolithic dating, were found in a grey silt below ten feet of peat.

\section{Electricity in Coal Mines}

Is a paper read by Mr. R. Nelson to the Institution of Electrical Engineers on December 1, a rotrospect is given of the use of electricity in coal mines during the last thirty years and also a forecast of what still remains to be done before the mines of Great Britain are fully electrified. In the year 1883, the first electric motor pump was used to pump water from a coal mine; it was only $1 \frac{1}{2}$ h.p., but there was then only very little mechanical power used for any purpose below ground. Twenty-five years ago the most disastrous explosion in the history of British mining, namely, that at Senghennydd Colliery, South Wales, had the effect of causing the miners to call for the removal of electricity from the pits. Happily, by the application of systematic stone dusting, a means was found of preventing the spread of an explosion of gas or coal-dust, and thereafter the miners' opposi- tion lessened, at any rate in degree, but it has not yet disappeared. During the last ten years, the coal industry has been greatly assisted by mechanized mining and mochanical methods of coal sorting. These, with normal development in other directions, have resulted in a total of more than two million horse power of motors installed in 1937, half of them being below ground. Accidont statistics are touched upon. It is recorded that, taken over ten years, 1927-1936 inclusive, electricity has been responsible for 224 out of 8,656 deaths, or $2 \frac{1}{2}$ per cent of the total loss of life in the pits. Electricity and compressed air are rival sources of power for the machine cutting of coal. In 1937 seventy per cent of the machine-cut coal was cut by electricity. It is satisfactory to learn that in some of the recently developed South Yorkshire and Nottinghamshire coalfields, their transmission mains are interconnected, a vory desirable example of co-operative working. The wider provision of cheap and unlimited current, by the 'grid' for example, would facilitate the use of electricity for all colliery purposes, and would improve the economics of the coal industry by materially assisting mechanical mining. The author concludes with an appeal to electrical engineers to capture the confidence of the miners.

\section{British Museum (Natural History): Acquisitions}

Mrs. Mary V. WALker has presented to the Department of Zoology a set of photographs which were taken by her husband, the late Dr. William D. Walker, depicting the early life history of kangaroos. The photographs show the kangaroo in all its stages from the newly born young one to the adult and mature individual. The first of the series shows the newly born kangaroo having just made its way into the pouch and it is seen adhering to one of the nipples. At this stage tho animal is very embryonic and bears but little resemblance to the massive creature into which it will grow, being scarcely more than an inch in length and looking more like a fragment of raw flesh than the young of any animal. A skin and seven sluulls of a rare species of otter (Paraony. microdon) have been presented by Mr. M. D. W. Jefferys. Mr. J. F. Perkins, assistant keeper in the Department of Entomology, spent six months from April until September 1938 in Sweden partly in the study of the important Thomson Collection of Ichneumonidæ (Hymenopterous insects the larvæ of which are parasitic on the larvæ of other insects), and partly in collecting insects, chiefly Ichneumonidæ, from the localities in Sweden where most of Thomson's specimens were obtained. More than 40,000 specimens of Hymenoptera were collected, of which 12,000 were Ichneumonidæ. A large quantity of the material obtained was identified and compared with the Thomson Collection before leaving Sweden, and the specimons so dealt with were found to represent 540 different species of which 260 were not previously to be found in the British Museum (Natural History). The collections obtained by Mr. Perkins constitute an important addition to the Entomological Department, and for the large number of specimens acquired and for the work done upon them in Sweden the Museum 